\title{
KAJIAN KONSEP SUSTANIBLE FARMING DALAM PEMBANGUNAN SEKTOR PERTANIAN
}

Endang Sudarsih

\begin{abstract}
Abstrak:
Pembangunan sektor pertanian masih relevankah menjadi prioritas pembangunan Indonesia di era globalisasi ekonomi saat ini, merupakan sebuah tantangan besar. Mengingat sebagian besar masyarakat kita adalah bertani dan menggantungkan hidup dari olahan hasil pertanian, maka pembangunan sektor pertanian adalah suatu keharusan. Konsep Bertani Secara Berkesinambungan (Sustainable Farming) menawarkan model bertani yang dapat meningkatkan produktivitas hasil pertanian, sehingga dapat mengurangi ketergantungan impor, terutama beras.
\end{abstract}

Kata Kunci: sustainable farming, inovasi, teknologi

Kajian ini dilatarbelakangi oleh ramainya perdebatan tentang larangan impor beras yang dikeluarkan pemerintah sejak tiga tahun yang lalu. Kebijakan larangan sementara untuk impor beras yang dikeluarkan pemerintah mendapat dukungan dari petani. Paling tidak pada musim panen raya, pasar tidak akan dibanjiri oleh beras impor, sehingga petani bisa menikmati harga yang baik.

Impor beras membuat harga produksi petani tidak mampu naik. Harga itu selalu anjlok takkala musim panen raya. Akibatnya produktivitas tidak meningkat karena tidak ada insentif yang bisa membuat petani bergairah meningkatkan produksi. Selain itu, kenyataannya harga gabah kering pada saat panen raya selalu jatuh, sehingga Surat Keputusan (SK) Menteri Perindustrian dan Perdagangan Nomor 9/MPP/Kep/1/2004 yang melarang impor beras satu bulan sebelum panen raya, selama panen raya dan dua bulan setelah panen raya disambut gembira. SK berlaku mulai 10 Januari 2004.

Dirjen Bina Produksi Tanaman Pangan Departemen Pertanian (2004), menyatakan bahwa kalau impor beras dihentikan, Indonesia pasti bisa mencapai swasembada beras, karena potensi persawahan yang ada, baik sawah berigasi teknis maupun sawah tadah hujan, sangat mendukung untuk mencapai swasembada beras itu. Bahkan menurutnya, produksi padi nasional terus menunjukkan peningkatan. Tahun 2001 produksi padi nasional mencapai 48,6 juta 
ton, tahun 2002 naik menjadi 51,16 juta ton, tahun 2003 naik lagi menjadi 52,1 juta ton. Pada tahun 2004 ini peroduksi padi nasional sudah memncapai 53,7 juta ton atau telah melebihi target yang ditetapkan sebanyak 53 juta ton. Kalau melihat keadaan di daerah, tahun 2004 ini besar kemungkinan akan mencapai 54 juta ton.

Sedangkan hasil penelitian Pusat Pengembangan Pangan justru memprediksi bahwa sampai tahun 2004 terjadi defisit beras. (Lihat Tabel 1). Proyeksi ini yang mendasari Bulog melakukan impor beras untuk memenuhi kebutuhan tersebut.

Tabel 1

Keseimbangan Permintaan dan Ketersediaan Beras Untuk Konsumsi Tahun 2001 - 2004

\begin{tabular}{|c|r|r|r|}
\hline Tahun & Kebutuhan & Produksi Tersedia & Defisit (Impor) \\
\hline 2001 & 32.771 .264 & 30.283 .326 & 2.487 .920 \\
\hline 2002 & 33.073 .152 & 30.586 .159 & 2.486 .993 \\
\hline 2003 & 33.372 .463 & 30.892 .021 & 2.480 .442 \\
\hline 2004 & 33.669 .384 & 31.200 .941 & 2.468 .443 \\
\hline
\end{tabular}

Sumber: Pusat Pengembangan Ketersediaan Pangan, 2002.

Kebijakan pemerintah yang elastis menyangkut pengadaan beras, dimana impor dibuka saat paceklik atau stok kosong akibat produksi kurang mencapai target dan ditutup pada saat kemampuan produksi padi dalam negeri sedang normal atau mencapai peak performance, cukup tepat. Kebijakan ini diperlukan guna melindungi kepentingan petani produsen agar harga jual gabah atau beras hasil panen mereka tidak anjlok, sekaligus tetap menjaga stok agar jutaan rakyat tidak mengalami kekurangan sumber pangan.

Meski demikian, perlu dicermati bahwa persoalan yang dihadapi petani tidak hanya impor tetapi juga ketersediaan pupuk, alat-alat pertanian, benih untuk meningkatkan produktivitas dan juga terjadinya pengurangan lahan secara terus menerus. Menurut Dirjen Bina Produksi Tanaman Pangan Deptan, Jafar Hafsah (2004) diperkirakan setiap tahun 47.000 hektare (ha) lahan pertanian yang potensial di Indonesia beralih fungsi atau terkonversi menjadi areal nonpertanian. Luas lahan yang beralih fungsi tersebut sebagian besar terjadi di Jawa yakni mencapai 43.000 ha/tahun. Secara nasional pada 1997 Indonesia memiliki lahan 
sawah 8,5 juta ha, namun hanya dalam tiga tahun berkurang 0,7 juta ha atau menjadi 7,8 juta ha pada 2000 atau rata-rata 230.000 ha/tahun.

Mengapa Indonesia yang pernah mengalami swasembada pangan, bahkan sempat mengekspor beras, menjadi importir beras pada masa krisis? Mengapa Indonesia yang kaya akan sumber daya alam dan tanah yang subur, justru membeli beras yang sesungguhnya dapat dihasilkan sendiri?

Meninjau hasil penelitian Arfian dan Arman (2000) tentang Kondisi dan Tantangan ke Depan Sub Sektor Tanaman Pangan di Indonesia, ada kemungkinan untuk memperbaiki dan meningkatkan produksi di sektor tanaman pangan maupun sektor argo lainnya, yang sesuai dengan kondisi alam dan budaya masyarakat Indonesia. Apalagi jika langkah ini didukung dengan kebijakan industri yang mengacu pada industri pertanian.

Selama ini kebijakan industri yang dikeluarkan pemerintah jarang, kalau tidak boleh dikatakan tidak pernah, mengkaitkan industri dengan sub sektor pertanian, atau industri yang mendukung produksi dan pengolahan hasil-hasil pertanian. Dampaknya sektor pertanian hanya diminati petani-petani di daerah pedesaan yang hanya menggunakan metode dan teknik tradisional yang sama dari waktu ke waktu selama bertahun-tahun.

Faktor yang lain adalah keinginan pengusaha untuk menjadi seorang "industrialis sejati" di sektor pertanian belum kelihatan, sehingga selama ini apa yang disebut produsen di Indonesia tidak lain hanyalah merupakan pedagang biasa yang kadang tidak bermodal selain hanya berlindung dibalik SK-SK yang menguntungkannya. Sehingga yang dilakukannya juga tidak lebih dari sekedar mengambil margin dari merakit dan menjual produk.

Hasil penelitian Arfian dan Arman (2000) telah memberikan ulasan tentang bagaimana kebijakan-kebijakan yang dibuat pemerintah berkaitan dengan sektor pertanian ini justru menimbulkan berbagai masalah baru yang dihadapi petani. Misal Program BIMAS pada tahun 1970-an dan program INSUS pada tahun 1980-an yang berdampak pada rendahnya tingkat kemandirian petani terutama kemandirian dalam bidang: 
(a) Teknologi, untuk mengelola lahan yang dimiliki atau digarap hanya bergantung pada satu pola tertentu saja. Petani menjadi sangat tergantung kepada produk atau inovasi yang datang dari luar.

(b) Pengaruh petani terhadap kekuatan pasar, terutama harga produk yang mereka hasilkan. Mata rantai yang terlalu panjang, ditambah tidak adanya kemauan yang serius dari pemerintah membuat petani selalu dalam posisi sebagai "risk taker" dan bukannya sebagai "price maker". Keuntungan terbesar bukannya ada di tangan petani sebagai produsen, akan tetapi justru ada di tangan pedagang perantara dengan berbagai tingkatannya.

(c) Akses terhadap modal, dimana petani dibuat selalu bergantung kepada kebijakan yang diambil pemerintah.

Berdasarkan kondisi pertanian di Indonesia dan konsep Sustainable Farming yang ditawarkan oleh Arfian dan Arman (2000), maka kajian ini menekankan pada:

1. Relevansi konsep sustainable farming dengan kondisi sektor pertanian di Indonesia.

2. Implikasi kebijakan industri sektor pertanian selama ini.

3. Relevansi sektor pertanian sub sektor tanaman pangan menjadi prioritas dalam pembangunan di Indonesia.

Pembahasan tema ini lebih merupakan kajian literatur dari hasil-hasil penelitian yang telah dilakukan oleh peneliti lain dibidang sektor pertanian serta kajian atas kebijakan pembangunan Indonesia, khususnya dalam bidang pertanian dan industri.

\section{Konsep Sustainable Farming}

Konsep ini sebenarnya sudah lama dikaji oleh para ahli ekologi, bahkan sejak tahun 1959 saat dampak negatif pemakaian bahan kimia di sektor pertanian muncul. Konsep ini memadukan pertanian dengan masukan rendah (low input agriculture), dimana petani bisa memperoleh keuntungan ekonomis dari usaha taninya tanpa terlalu mengorbankan lingkungan. Dengan metode ini petani tidak menafikan sama sekali masukan bahan-bahan kimia, akan tetapi juga tidak menggunakannya secara berlebihan. Petani dituntut untuk bisa kreatif ataupun 
membuka ulang metode-metode yang banyak digunakan oleh para orang tua dulu yang ternyata ramah lingkungan, dikombinasikan dengan inovasi-inovasi terbaru.

Ada beberapa kendala yang mungkin dihadapi dalam melaksanakan konsep sustanible farming ini, yaitu:

1. Persepsi dari petani. Hal ini merupakan halangan yang paling serius, terutama di negara-negara yang sedang berkembang, untuk mengaplikasikan suatu metode atau inovasi baru. Inovasi baru tidak akan dicoba oleh petani, bila mereka belum yakin benar akan efektivitasnya, dan keuntungan ekonomisnya.

2. Kepraktisan. Cara-cara bertani seperti yang diuraikan di atas memang tidak praktis, bila dibandingkan dengan menggunakan bahan-bahan kimia biasa. Selain itu juga lebih memerlukan banyak tenaga kerja dan waktu.

3. Kebijakan. Adanya paket-paket KUT (Kredit usaha Tani), atau "crash-crash program" yang lain, terkadang dalam pelaksanaannya seperti dipaksakan ke petani. Hal ini membuat petani yang sebenarnya tidak memerlukannya, terpaksa mengambil juga karena tidak mau repot di kemudian hari, sehingga terjadi ketidak efisienan penggunaan KUT, yang berakibat pada kredit macet.

\section{Pembahasan}

Sebagaimana diketahui, negara sedang berkembang biasanya mempunyai perkembangan komparatif untuk produk-produk mineral dan pertanian. Hanya sedikit sekali negara, yang pada awal pertumbuhan ekonominya sumber devisanya berasal dari industri manufaktur dan jasa. Oleh karena itu, jika suatu negara yang kaya akan sumber-sumber mineral seperti minyak, maka sektor pertanian harus memerankan peran kunci dalam menyediakan devisa yang digunakan untuk mengimpor barang-barang modal yang belum dapat diproduksi sendiri. Demikian pula Indonesia, sebagai salah satu negara yang kaya akan sumber-sumber mineral dan pertanian.

\section{Relevansi konsep sustainable farming}

Konsep sustainable farming yang ditawarkan Arfian dan Arman (2000) masih sangat relevan untuk diterapkan pada sektor pertanian di Indonesia, 
meskipun ada beberapa kendala dalam pelaksanaanya. Sudah saatnya Indonesia memperbaiki sistem dan teknologi pengolahan pertanian dan hasil-hasilnya.

Pertanian di Amerika Serikat dan Jepang sedemikian majunya, meskipun pola yang digunakan tidak sama, namun keduanya sama-sama mempergunakan teknologi dan inovasi yang tinggi. Amerika lebih cenderung dan sesuai dengan pola mekanisasi pertanian atau pengenal mesin-mesin produksi guna menggantikan tenaga kerja manusia. Hal ini dikarena lahan pertanian per orang di Amerika sangat luas, sedang tenaga kerja langka dan mahal. Berbeda dengan Jepang, yang lebih menekankan pada inovasi biologis (bibit unggul) dan produkproduk kimia penunjang pertanian (pupuk, insektisida, dll).

Pola mekanisasi tidak tepat bagi Indonesia karena kepemilikan lahan per orang sangat sempit dan tenaga kerja sangat murah, bilang dibandingkan sektor industri. Pola Jepang juga kurang tepat karena sebagian besar pendidikan petani rendah, sehingga daya inovasinya juga rendah.

Terdapat pola lain yang mulai mendunia, yaitu tanaman-tanaman yang justru tidak mengandung bahan-bahan kimia karena banyak orang mulai beralih ke tanaman-tanaman yang organik. Pola ini relatif lebih sederhana untuk bisa diterapkan oleh petani Indonesia, apalagi saat ini kesadaran masyarakat akan hidup sehat dan ramah lingkungan menjadi lebih baik. Ini menjadi peluang pasar yang cukup besar.

Namun demikian, mengingat adanya kendala-kendala penerapan sustainable farming sebagaimana telah disebutkan, maka perlu adanya sosialisasi yang menyeluruh dan benar untuk mengubah persepsi maupun paradigma petani tentang keuntungan ekonomis pola ini dan efektivitasnya. Selain itu butuh waktu lama karena petani harus dibiasakan dengan metode yang baru yang tidak praktis, sehingga perlu dukungan modal dan motivasi sepenuhnya dari pemerintah dan masyarakat setempat dalam pencapaian hasil. Peningkatan pendidikan dan penyuluhan perlu diprogramkan juga untuk membentuk kemandirian petani, sehingga kesuksesan dan keberlanjutan program ini bisa dipertanggungjawabkan. Selain itu, ada upaya-upaya yang sungguh-sungguh dari petani untuk meningkatkan pengetahuan dan menerapkan teknologi dan inovasi biologis di 
sektor pertanian yang dapat memacu produktivitasnya. Ada baiknya petani juga mengorganisasikan diri secara rapi untuk bekerja sama secara mandiri. Hal ini juga dapat meningkatkan kedudukan petani untuk menuntut haknya, serta dapat menjadi kekuatan untuk mempengaruhi pengambilan kebijakan nasional yang menguntungkan petani (sektor pertanian).

Untuk itu penekanan Arfian dan Arman (2000) tidak hanya menekankan pada pupuk dan pengendalian hama saja untuk meningkatkan daya saing global atas hasil-hasil pertanian. Peningkatan pengetahuan peneliti dan petani tentang biologi dalam dunia pertanian untuk melakukan inovasi-inovasi baru (bibit-bibit unggul) sangat mendesak sekali, untuk meningkatkan produktivitas dan output sektor pertanian.

Selain itu, harus juga ditunjang dengan fasilitas dan sarana lain yang didukung sepenuhnya oleh pemerintah seperti kebijakan makroekonomi yang mendukung dan tidak merugikan petani, membangun infrastruktur yang dibutuhkan di sektor pertanian, terciptanya kelembagaan yang melayani pertanian dan agrobisnis, yaitu semacam kelembagaan pemasaran yang efisien, serta lembaga keuangan yang mendukung kebutuhan keuangan di sektor pertanian. Pemerintah juga perlu mengurangi, atau bila mungkin meniadakan sama sekali, pajak ekspor hasil pertanian untuk memotivasi dan meningkatkan daya saing hasil pertanian di pasar global maupun domestik.

\section{Implikasi kebijakan industri terhadap sektor pertanian}

Keragaman sektor industri di Indonesia telah menghadapkan para perencana ekonomi Indonesia pada suatu dilema. Bila tujuan yang diutamakan adalah penciptaan lapangan kerja dan penghapusan kemiskinan, maka sumbersumber ekonomi yang tersedia harus disalurkan ke dalam usaha-usaha yang membantu sektor kerajinan rumah tangga yang tidak produktif dan tidak banyak diketahui. Bila tujuan yang diutamakan adalah pertumbuhan ekonomi maka sumber-sumber tersebut haruslah diarahkan kepada usaha-usaha pengembangan perusahaan-perusahaan industri besar. 
Salah satu strategi industialisasi yang dilaksanakan Indonesia, sejak jaman pemerintahan orde baru adalah Industri Substitusi Impor (ISI). ISI ini diharapkan bisa menghasilkan barang-barang baru di dalam negeri yang semula diimpor. Setelah substitusi impor ini berhasil, baru kemudian sebagian hasil produknya diekspor. Jadi substitusi ini memegang peranan penting dalam mengenalkan barang-barang baru yang dulunya diimpor dan kemudian dihasilkan sendiri.

Dalam pelaksanaan kebijaksanaan ISI ini ada berbagai masalah yang dihadapi oleh Indonesia. Pertama, kualitas barang yang dihasilkan di dalam negeri sebagai barang substitusi impor sering jauh lebih rendah daripada hasil produksi luar negeri. Kualitas barang yang rendah ini akan sulit diekspor. Kedua, biaya produksi. Pada tahap awal industrialisasi biasanya dibutuhkan biaya yang sangat besar yang digunakan untuk mendidik tenaga kerja, membeli mesin-mesin dan membeli bahan-bahan baku yang diperlukan. Jadi modal yang dibutuhkan sangat banyak. Oleh karena negara itu hanya memiliki modal yang sedikit, maka dalam tahap awal industrialisasinya terpaksa mendatangkan modal dan tenaga kerja dari luar negeri.

Namun demikian, Clive Gray (Tambunan, 2001) telah mengungkapkan bahwa berbagai industri perakitan yang telah dibangun di Indonesia selama satudua dasawarsa lalu, misalnya industri otomotif, ternyata tidak efisien dan menghasilkan "nilai tambah negatif" jika diukur dengan harga pasaran dunia. Meskipun produksi dalam negeri dari produk akhir menguntungkan para industrialis karena proteksi efektif atau effective rate of protection (proteksi atas nilai tambah domestik) yang tinggi sekali, namun nilai input-input (bahan-bahan baku dan komponen-komponen) pada harga pasaran dunia sering melebihi nilai produk akhir pada harga pasaran dunia. Dengan demikian, maka jumlah devisa dapat dihemat dengan berkurangnya impor produk akhir dari luar negeri.

Oleh karena strategi substitusi imporyang telah ditempuh Indonesia selama kurang lebih 20 tahun, kurang berhasil membangun struktur industri yang kokoh dengan adanya daya saing internasional yang kuat, maka strategi tersebut secara pelan-pelan bergeser ke strategi promosi ekspor, yang terutama untuk komoditi non-migas. Apalagi Indonesia pada saat itu dihadapkan pada kenyataan bahwa 
penerimaan devisa dari migas tidak selamanya dapat diharapkan, baik karena cadangan migas kita yang relatif terbatas maupun karena fluktuasi harga migas di pasar internasional yang sering tidak menentu.

Untuk kedepannya, dalam memilih strategi industrialisasi yang tepat untuk diterapkan di Indonesia, maka ada sejumlah aspek yang perlu dipertimbangkan, yaitu:

1. Melihat kenyataan bahwa ada dua sektor ekonomi besar, dimana Indonesia memiliki keunggulan komparatif yaitu pertanian dan pertambangan. Untuk itu dalam proses industrialisasi harus dikembangkan keterkaitan produksi ke depan (forward) dan ke belakang (backward) antara kedua sektor primer tersebut dengan industri manufaktur.

2. Dikembangkan keterkaitan produksi antara sektor industri manufaktur dengan sektor-sektor sekunder dan sektor tersier, juga antar subsektor/kelompok industri.

3. Strategi industrialisasi yang tepat bagi Indonesia adalah yang memfokuskan pada perkembangan kelompok industri:

a. Industri-industri yang memakai komoditas-komoditas pertanian dan pertambangan sebagai bahan baku utama.

b. Industri-industri mesin, alat-alat produksi, komponen, spare part, dan material-material lain, yang dapat mengurangi ketergantungan impor.

c. Industri-industri yang outward looking-oriented, terutama industri yang dapat menghasilkan barang-barang untuk kebutuhan pasar domestik tapi mempunyai daya saing global yang tinggi.

4. Pengembangan sektor industri manufaktur harus berdasarkan spesialisasi atas faktor-faktor keunggulan komparatif yang dimiliki Indonesia dan faktor-faktor keunggulan kompetitif yang dapat dikembangkan.

\section{Sektor Pertanian Sebagai Prioritas Pembangunan di Indonesia.}

Tidak dapat diingkari bahwa salah satu penyebab krisis ekonomi yang dialami Indonesia selama periode 1997-1999, adalah karena kesalahan strategi industrialisasi selama pemerintahan orde baru yang tidak berbasis pada 
keunggulan komparatif besar yang dimiliki Indonesia, yaitu pertanian. Selama krisis terbukti bahwa sektor pertanian masih mampu memiliki laju pertumbuhan yang positif, walaupun dalam persentase yang kecil. Sedangkan sektor industri manufaktur mengalami laju pertumbuhan yang negatif di atas satu digit.

Pengalaman di banyak negara industri maju (AS, Jepang, dan negaranegara di Eropa) menunjukkan bahwa mereka memulai industrialisasi setelah atau bersamaan dengan pembangunan di sektor pertanian. Ada beberapa alasan kenapa pembangunan sektor pertanian yang kuat esensial dalam proses industrialisasi di negara seperti Indonesia, yakni sebagai berikut:

1. Sektor pertanian yang kuat, berarti ketahanan pangan terjamin. Hal ini merupakan salah satu prasyarat penting agar proses industrialisasi pada khususnya dan pembangunan ekonomi pada umumnya bisa berlangsung dengan baik. Ketahanan pangan berarti tidak ada kelaparan dan ini menjamin kestabilan sosial dan politik, yang selanjutnya menjamin proses pembangunan ekonomi atau industrialisasi dapat berlangsung tanpa gangguan.

2. Di sisi permintaan agregat, pembangunan sektor pertanian yang kuat membuat tingkat pendapatan riil per kapita di sektor tersebut tinggi. Hal ini merupakan salah satu sumber permintaan terhadap barang-barang non makanan, khususnya manufaktur di Indonesia, dimana sebagian besar penduduk tinggal di pedesaan dan memiliki sumber pendapatan langsung maupun tidak langsung dari kegiatan pertanian. Jelas sektor ini merupakan motor utama penggerak industrialisasi, terutama di pedesaan. Selain adanya keterkaitan konsumsi dan pendapatan, sektor petanian juga berfungsi sebagai sumber pertumbuhan di sektor manufaktur lewat intermediate demand effect atau keterkaitan produksi: output dari industri menjadi input bagi pertanian.

3. Di sisi penawaran, sektor pertanian merupakan salah satu sumber input bagi sektor industri manufaktur yang mana Indonesia memiliki keunggulan komparatif. Dengan kata lain, lewat keterkaitan produksi, pertumbuhan produktivitas atau output, di sektor pertanian bisa menjadi sumber pertumbuhan output di sektor industri manufaktur. Pembangunan yang baik di sektor pertanian bisa menghasilkan money surplus, dan menjadi sumber 
investasi bagi industri manufaktur, khususnya industri berskala kecil di pedesaan.

Tanpa suatu peningkatan output atau produktivitas di sektor pertanian, sektor industri manufaktur tidak dapat meningkatkan outputnya (pertumbuhan tinggi sulit dicapai). Oleh karena itu, sektor pertanian memainkan suatu peranan penting dalam pembangunan sektor industri manufaktur. Data Bank Dunia (1997) mengenai pertumbuhan output di dua sektor tersebut di sejumlah negara di Asia untuk periode 1980-1995, menunjukkan adanya suatu korelasi positif antara pertumbuhan output di sektor pertanian dan pertumbuhan output di sektor industri.

Berdasarkan uraian di atas, sektor pertanian tepat dikatakan sebagai andalan perekonomian nasional, yang berarti juga sebagai motor penggerak sektor industri manufaktur. Konsep dasarnya adalah sebagaimana yang dapat dikutip dari Simatupang dan Syafa'at (2000), "Sektor andalan perekonomian adalah sektor yang memiliki ketangguhan dan kemampuan tinggi. Sektor andalan merupakan tulang punggung dan mesin penggerak perekonomian, sehingga dapat pula disebut sebagai sektor kunci atau sektor pemimpin perekonomian nasional."

Bila meninjau kemali tentang impor beras untuk memenuhi kebutuhan masyarakat, alangkah ironis sektor pertanian di Indonesia ini sebagai salah satu sektor keunggulan komparatif yang masih dimiliki Indonesia terabaikan. Dengan demikian, masih sangat laik untuk memprioritaskan pembangunan di Indonesia ini pada sektor pertanian, terutama tanaman pangan.

Situasi defisit beras, apabila berkelanjutan akan berdampak pada meningkatnya ketergantungan pada pangan impor, yang pada gilirannya melemahkan tingkat kepastian pangan dan ketahanan pangan nasional. Untuk menekan tingkat defisit tersebut, perlu upaya-upaya yang diarahkan pada peningkatan kemampuan penyediaan (produksi) dan penurunan tingkat permintaan (konsumsi).

Untuk meningkatkan kemampuan produksi beras nasional, beberapa upaya dapat dilakukan seperti pemeliharaan kapasitas sumber daya lahan dan perairan, perluasan lahan baku untuk produksi, peningkatan intensitas tanam, peningkatan 
produktivitas tanaman serta penekanan kehilangan hasil. Beberapa upaya yang dibutuhkan untuk memelihara kapasitas sumberdaya produksi pangan adalah:

a. Pembangunan dan rehabilitasi sistem irigasi, serta perbaikan pengelolaan sumber daya air dalam rangka menyediakan air yang cukup untuk pertanian. Untuk itu perlu dilakukan:

(i) Perbaikan dalam pengaturan, kelembagaan pengelolaan, dan pemanfaatan sumberdaya air, seperti penatagunaan ruang/wilayah dan penerapan peraturan secara disiplin, oleh Pemda dan Depdagri;

(ii) Fasilitasi pengelolaan sumber daya air dan pengairan oleh Meneg Kimpraswil;

(iii)Fasilitasi pemanfaatan lahan pertanian secara produktif, efisien dan ramah lingkungan oleh Deptan; dan

(iv)Pemanfaatan dan pengawasan sumberdaya lahan dan perairan oleh masyarakat.

b. Menekan berlanjutnya alih fungsi lahan beririgasi kepada usaha non pertanian. Hal ini menyangkut pengaturan/pembatasan dengan sistem insentif yang dilaksanakan secara lintas institusi antara lain:

(i) Penetapan peraturan dan penerapannya secara disiplin oleh Pemda dan BPN;

(ii) Fasilitasi bagi pengembangan berbagai usaha masyarakat berbasis pertanian oleh Departemen Teknis; dan

(iii)Pengawasan oleh masyarakat sebagai pelaku usaha.

c. Membuka lahan pertanian baru pada lokasi-lokasi yang memungkinkan dengan tetap memperhatikan rencana tata ruang wilayah dan kaidah-kaidah kelestarian lingkungan; yang difasilitasi oleh Pemda.

Adapun upaya untuk memacu peningkatan produktivitas usaha pangan mencakup: (1) penciptaan varietas unggul baru, dan teknologi berproduksi yang lebih efisien; (2) teknologi pasca panen untuk menekan kehilangan hasil; dan (3) Teknologi yang menunjang peningkatan intensitas tanam. Upaya ini dilaksanakan secara sinergis oleh institusi penelitian, pengembangan dan penyuluhan lingkup Departemen Pertanian, Ristek/BPPT, Perguruan Tinggi, dan Lembaga/Dinas 
Teknis setempat yang melaksanakan alih pengetahuan dan teknologi kepada masyarakat.

\section{Kesimpulan}

Berdasarkan uraian dalam pembahasan di atas ada beberapa hal yang dapat digaris bawahi di sini, yaitu:

1. Konsep sustainable farming, sangat dapat dan mungkin diterapkan di Indonesia, mengingat negara-negara industri maju menerapkan pola dan metode ini dalam sektor pertaniannya. Indonesia lebih cocok menggunakan teknik atau metode ini dari pada melakukan pola mekanisasi. Hal ini dikarenakan lahan petani Indonesia tidak terlalu luas, sedang tenaga kerja (pengangguran) relatif banyak.

2. Kebijakan dan strategi industrialisasi yang diterapkan di Indonesia harus memperhatikan sektor pertanian sebagai salah satu keunggulan komparatif yang dimiliki. Indutrialisasi ini justru harus menjadikan keunggulan komparatif di sektor pertanian menjadi keunggulan kompetitif sehingga mempunyai nilai tambah (added value) yang lebih tinggi.

3. Sektor pertanian masih merupakan prioritas dalam pembangunan ekonomi di Indonesia, karena sektor pertanian dan pertambangan merupakan faktor keunggulan komparatif yang dimiliki oleh bangsa Indonesia.

\section{Daftar Pustaka}

Arfian, Muhammad dan Arman Wijonarko, 2000, Kondisi dan Tantangan ke Depan Sub Sektor Tanaman Pangan di Indonesia, Proceeding of the Fourth Symposium on Agri-Bioche.

Arsyad, Licolin, 1996, Ekonomi Pembangunan, Yogyakarta: Penerbit STIE YKPN

Chenery, H.B. Industrialisasi dan Pertumbuhan Ekonomi: Pandangan Alternatif Atas Asia Timur. Dalam helen Hughes (ed.), 1992, Keberhasilan Industrialisasi di Asia Timur, Jakarta: PT. Gramedia Pustaka Utama.

Chenery, H.B, Robinson, S dan Syrquin, Moises. 1996. Industrialization and Growth A Comparative Study, Oxford University Press untuk Bank Dunia.

Kuncoro, Mudrajat, 2004, Ekonomi Pembangunan, Jakarta 
Tambunan, Tulus T.H, 2001, Industrialisasi di Negara Sedang Berkembang: Kasus Indonesia, Jakarta: Penerbit Ghalia Indonesia.

Todaro, Michael P, 1998, Pembangunan Ekonomi Di Dunia Ketiga, Jakarta:

Penerbit Erlangga

Riedel, James. Pembangunan Ekonomi di Asia Timur. Dalam Helen Hughes (ed.), 1992, Keberhasilan Industrialisasi di Asia Timur, Jakarta: PT. Gramedia Pustaka Utama.

Simatupang, Pantjar dan Niswar Syafa'at, 2000, " Strategi Pembangunan Ekonomi Nasional Industrialisasi Berbasis Pertanian.”. Makalah dalam Konggres XIV ISEI, 21-23 April 2000, Makassar. 